\title{
CHALLENGES IN PRESENTING ACADEMIC CRITICISM: CASE STUDY OF INDONESIAN STUDENTS
}

\author{
Nova Ariani \\ Universitas Negeri Malang \\ nova.ariani.fs@um.ac.id
}

\begin{abstract}
Presenting academic criticism in academic papers is one of the most challenging study tasks for students from NonEnglish-Speaking Background (NESB) countries studying in Australia. Most lecturers in Australian university expect students to engage in critical discussion and put their adversarial position in academic writing. This study investigates the challenges experienced by Indonesian students studying in Australia in presenting academic criticism. Data were collected through questionnaires along with two focus group interviews of Indonesian graduate students in Australia. The study has found that cultural values, socio-political situations, and previous educational experience in Indonesia have contributed to participants' limited writing experience and limited critical literacy practice. All of these have manifested to their struggle of presenting academic criticism and writing according to the expected dominant discourse in Australia.
\end{abstract}

Keywords: Academic Criticism, Indonesian Students, Academic literacies, Writing Practices

\section{INTRODUCTION}

International students from South-East Asia, including Indonesia, have been choosing Australia as a destination to continue their higher education for many years. The largest scholarship provider for Indonesian students overseas in 1998-1999 was Australia (Indonesian Ministry of Research, Technology, and Higher Education as cited in Sirozi, 2008). Since then, there have been about 16,000 Indonesian enrolments in Australian institutions (Department of Foreign Affairs and Trade, 2010). However, Phan (2011) has argued that while this has contributed to a multicultural academic environment in Australian universities, on the other hand, it also raises the question of cross-cultural adjustment. Golebiowski (1998) states that "writing is an expression of culture, and the native culture, in particular the educational system of the writer's culture, influences his/her writing habits." When multilingual writers compose a piece of writing, they inevitably present ideas within words that embody their perspectives, which are shaped by their respective cultures and languages, and it requires inordinate effort to reorientate themselves to other discourses (Canagarajah, 2002). However, this situation is even more problematic when individuals with multiple writing practices are required to conform to the dominant conventions of academic writing in Australia which demand Western-style deductive, critical debate as the norm in much academic writing (Durkin, 2008).

In regard to writing, multilingual writers writing in English have been stigmatized as 'illogical in thinking and incoherent in communication by virtue of their deficit L1 and native culture' (Canagarajah, 2002, p.12). In this case, the argument which stated groups of international students are deficient comes from a concept of 'conceptual colonisation' (Biggs, 1997). It is where one takes one's own limited cultural understanding and as a consequence, differences manifested by international students are deviations from one's norms and need to be corrected (Biggs, 1997). The previous situation urges Silva, Leki, \& Carson (1997) develop a more global and inclusive understanding of writing to avoid academic writing being seen as a monolinguistic, monocultural and ethnocentric enterprise. However, after more than a decade since their proposition, "universities are still far from tolerant of issues faced by multilingual writers, demonstrating narrowness and neglect in acknowledging international students' different way of writing in mainstream composition studies" (Silva, Leki, \& Carson, 1997, p.399-400). Thus, there is a need for further investigation regarding the challenges faced by Indonesian students studying in Australia in articulating academic criticism in English academic writing.

Academic criticism is defined as a statement which reflects a discrepancy between a stance of a researcher/author, on the one hand and that of another researcher or the discourse community as a whole, on the other (Salagar-Meyer, Alcaraz-Alriza, \& Zambrano, 2003). Academic criticism focuses on 
previous research gaps and/or limitations that express judgments of academic achievement and quality of previous research (Salager-Meyer \& Alcaraz-Ariza, 2003). In this study, academic criticisms is defined as a text that presents arguments and critically evaluates concepts and theories in scholarly articles. During their study in Australia, my participants need to present it in one of their assignments by choosing two peer-reviewed scholarly articles to be critically evaluated based on their understanding of different research perspectives and methodologies. Thus, this study is attempted to answer the following research question: What challenges do some Indonesian graduate students experience in presenting academic criticism in their English academic papers in Australia? discussed.

In the next section, literature review in regard to writing practices of Indonesian students will be

\section{LITERATURE REVIEW}

\section{Writing Practices of Indonesian Students}

English has a status of a foreign language in Indonesia and students learn it from junior high to senior high school as a compulsory subject. Currently, it is taught from the primary, even kindergarten in some areas to university level. In addition, Dardjowidjojo (2000) explains that the term 'English as the first foreign language' is used and not as second language because most Indonesians are bilingual with Indonesia, as the national language (that is, a second language) and their local/ vernacular language as their mother tongue.

In regards to English writing, many language teachers complain that without time for practicing speech and writing essays, no language teacher can guide his or her students toward an acceptable level of productive language competence (Buchori, 2001). Alwasilah (2001) investigated a case of writing involving 100 college freshmen representing different high schools in West Java and its vicinity) and found the following issues:

1. Writing has been the most neglected subject in high schools.

2. Writing is the most difficult language skill to acquire by students and to teach by teachers.

3. High school students as well as college students have been subjected to inexperienced teachers or professors.

4. Writing classes are dominated by discussion on grammar and theories of writing with less exposure to the practice of writing.

5. In most cases, students' writings are not corrected or returned to the students.

6. The most effective and the only way of teaching writing is through the practice of writing.

Concerning cultural issues, Kurniati (2008) discovered that some Indonesian postgraduate students at Monash University were indirect in presenting arguments, which led to circularity in the expression of ideas and concomitant problems in composing effective sentences. Thus, she argued that her participants' culturally-determined tendency toward some values was likely to contribute to their difficulties. Kuniati (2008) found major contributing factors to students' problems are negative transfer, overgeneralization, the influence of students' cultural values, inadequate English proficiency, difficulties in synthesizing ideas, a lack of thoroughness in checking writing, lack of comprehension of the topic discussed, and unfamiliarity with the academic writing genre. The study found that students rely on a range of strategies in attempting to overcome their academic writing problems, including the use of dictionaries and thesaurus, and frequently consulting with friends, language support staff and lecturers. Ignatius (1999, as cited in Cahyono, 2001) investigated the features of English academic writing by Indonesian students in the English department in Malang and found that the rhetorical development of ideas in the essays did not entirely follow the linear staging of the information as expected by Englishspeaking readers. He stated that many essays were marked by indirect approaches such as circular and digressive developments.

\section{Writing As a Site of Struggle to Present Academic Criticism}

With the rise of the New Order in Indonesia, the opportunity progress to criticize in social context and education declined. The government did not allow critics express their thoughts and Indonesian academics, especially in the area of the social sciences, including history, were restricted to voice their thoughts and this restriction included not talking about cases of the unconstructive impact of the New Order (Alkatiri, 2013). Currently, the difficulties of developing one's own opinion can also be observed among Indonesian students studying in Indonesian universities (Chandra, 2004).

Coming to Australia, Indonesian students who have been educated and practiced the literacy practices under the New Order will face a more complex situation. An Indonesian student studying in America mentioned the political reasons behind her reluctance to be openly critical in her writing and she further explained that criticism was not acceptable for her and said that it was dangerous because 
"criticizing people who have power could be considered a subversive act" (Angelova \& Riazantseva,1999, pp. 504-505).

\section{METHODOLOGY}

Two focus groups were carried out in order to have richer and more complex data because too many groups would increase the complexity of the data analysis (Bryman, 2012). There are 8 participants with pseudonyms Anir, Toni, Melati, Sheila for the first focus group and Olivin, Sekar, Maiza, and Damar for the second focus group. Questionnaire was also distributed to the participants to have the participants' profile in regard to their educational background and writing experience.

Table 1 shows the participants' profile taken from the questionnaires.

\begin{tabular}{|c|c|c|c|c|c|c|c|}
\hline \multirow[b]{2}{*}{ No. } & \multirow[b]{2}{*}{ Participant } & \multicolumn{2}{|c|}{ Study Program } & \multirow[b]{2}{*}{ Occupation } & \multirow[b]{2}{*}{ Gender } & \multirow[b]{2}{*}{ Age } & \multirow{2}{*}{$\begin{array}{l}\text { Years of } \\
\text { English } \\
\text { Academic } \\
\text { Writing } \\
\text { Experience } \\
\end{array}$} \\
\hline & & $\begin{array}{l}\text { Bachelor } \\
\text { program in } \\
\text { Indonesia }\end{array}$ & $\begin{array}{l}\text { Master } \\
\text { program in } \\
\text { Monash } \\
\text { University } \\
\end{array}$ & & & & \\
\hline 1. & Anir & $\begin{array}{l}\text { English } \\
\text { Education }\end{array}$ & $\begin{array}{l}\text { TESOL } \\
\text { International }\end{array}$ & $\begin{array}{l}\text { English } \\
\text { teacher in } \\
\text { Aceh }\end{array}$ & $F$ & 26 & $\begin{array}{l}9 \text { years } \\
\text { E.g.: } \\
\text { assignments, } \\
\text { IELTS \& } \\
\text { TOEFL } \\
\text { preparation } \\
\text { paper, final } \\
\text { project*}^{*}\end{array}$ \\
\hline 2. & Toni & $\begin{array}{l}\text { English } \\
\text { education }\end{array}$ & $\begin{array}{l}\text { TESOL } \\
\text { International }\end{array}$ & $\begin{array}{l}\text { English } \\
\text { teacher in } \\
\text { Yogyakarta }\end{array}$ & $M$ & 25 & 9 years \\
\hline 3. & Sheila & $\begin{array}{l}\text { English } \\
\text { Education }\end{array}$ & $\begin{array}{l}\text { TESOL } \\
\text { International }\end{array}$ & $\begin{array}{l}\text { English } \\
\text { lecturer in } \\
\text { Jakarta }\end{array}$ & $F$ & 30 & 2 years \\
\hline 4. & Melati & $\begin{array}{l}\text { International } \\
\text { Relation }\end{array}$ & $\begin{array}{l}\text { International } \\
\text { Education }\end{array}$ & $\begin{array}{l}\text { Administrator } \\
\text { for academic } \\
\text { mobility } \\
\text { service in } \\
\text { University in } \\
\text { Surabaya }\end{array}$ & $F$ & 30 & $\begin{array}{l}\text { Less than } 6 \\
\text { months }\end{array}$ \\
\hline 5. & Damar & $\begin{array}{l}\text { English } \\
\text { Education }\end{array}$ & $\begin{array}{l}\text { TESOL } \\
\text { International }\end{array}$ & $\begin{array}{l}\text { English } \\
\text { teacher in } \\
\text { Samarinda }\end{array}$ & $F$ & 29 & 2 years \\
\hline 6. & Sekar & $\begin{array}{l}\text { English } \\
\text { Education }\end{array}$ & $\begin{array}{l}\text { TESOL } \\
\text { International }\end{array}$ & $\begin{array}{l}\text { English } \\
\text { lecturer in } \\
\text { Surakarta }\end{array}$ & $F$ & 29 & 8 years \\
\hline 7. & Olivin & $\begin{array}{l}\text { English } \\
\text { Education }\end{array}$ & $\begin{array}{l}\text { TESOL } \\
\text { International }\end{array}$ & $\begin{array}{l}\text { English } \\
\text { lecturer in } \\
\text { Ambon }\end{array}$ & $F$ & 29 & 11 years \\
\hline 8. & Maiza & Linguistics & $\begin{array}{l}\text { Applied } \\
\text { Linguistics } \\
\text { for } \\
\text { Language } \\
\text { Teachers } \\
\end{array}$ & $\begin{array}{l}\text { English } \\
\text { lecturer in } \\
\text { Padang }\end{array}$ & $F$ & 31 & 12 years \\
\hline
\end{tabular}

${ }^{*}$ All participants wrote assignments and final project in their undergraduate programs in English except Melati and all participants took IELTS and TOEFL preparation before coming to Australia.

${ }^{*} \mathrm{TOEFL}$ is the Test of English as a foreign language. Many Australian universities ask international students to have IELTS instead of TOEFL in order to gain entry to the study program.

*IELTS is the International English Language Testing System. It is a test for students who need to demonstrate English language proficiency to gain entry to universities or training programs in English speaking country. International students have to score 6.5 or more out of 9 in order to enter Australian education system (Gunawardena \& Wilson (2012) 
To analyse the data, thematic analysis was applied in trying to uncover the participants' experience and opinions. Thematic analysis is a method for identifying, analysing, and reporting patterns (themes) within raw data (Braun \& Clarke, 2006). Bryman (2012) states thematic analysis is one of the most common approaches and it requires the search for themes that can be discerned in much qualitative data analysis. These theme and subthemes are the product of a thorough reading and rereading of the transcripts (Bryman, 2012). The analysis was started with the identification of the emerging themes then some words and phrases that were somewhat similar were grouped into the same category.

\title{
FINDINGS AND DISCUSSION
}

\section{Challenges in Presenting Academic Criticism}

The data shows that the problems in the presentation of academic criticism are not solely rooted in the language barrier, in this context, English. Some challenges that the participants mentioned in regards to writing academic criticism are limited writing experience and limited critical literacy practice.

\section{'I haven't written a lot'}

According to the data, the limited writing experiences in both languages, Bahasa Indonesia and English are the most influential reason why the participants face difficulties in writing. The participants did not have a lot of writing practice when they were educated in Indonesia. All participants agreed that writing in a different language is very daunting and difficult as literacy practices are culturally constructed and similar to all cultural phenomena, they have roots in the past (Barton \& Hamilton, 1998). Participants shared their writing experience in Indonesia.

\section{"About my first degree study I didn't write much but I get some experience some writing experience which is my thesis conduct research" (Toni)}

Sheila: I haven't had like many experience writing in Indonesia so I couldn't really.. I couldn't really catch the difference between the two (English and Indonesian academic essays).

Leki (1992) argued that rules and strategies to present ideas are not innate, universal, or strictly logical and these rhetorical preferences and convention are taught at schools. However, from the data, it seems that the participants have not been fully acculturated into academic writing in Bahasa Indonesia by their past educational experiences in Indonesia. Once they entered university, their major required them to compose all assignments and their final project in English.

\begin{abstract}
"When I was senior high school actually my teacher taught me for academic writing, I didn't really write academically and my mostly my Bahasa Indonesia teacher even though she taught me how to write academically, but I think that at that time she didn't really teach me how to write it academically because she thought that all of us we can speak Bahasa Indonesia, so yeah about academic words and everything we were not familiar with that even though then I realize that there are differences between Indonesian language that we use every day and then the formal ones, the academic ones." (Damar)
\end{abstract}

This finding is in line with Alwasilah (2001) as stated in literature review that writing is the most neglected aspect of ELT, which is also experienced by the participants in their literacy practices. Another participant, Maiza stated that she is concerned of her status as a lecturer of English because she has not published any writing. The writing papers that she did were only assignments related and she really hopes to write and publish more. Moreover, she added how her lecturers in Indonesia did not explain comprehensively what genre to write and when she and her friends got the writing assignment, they just put something and compiled it by taking from some sources. She mentioned how this act could be considered plagiarism and stated that she got more writing experience in Australia.

Before departing to Australia, all of my participants mentioned that they were required to take IELTS preparation and some bridging courses to prepare them for their study. In Australia, all participants mentioned that they mostly write argumentative texts and present academic criticism is a requirement in one of their subjects. However, embarking a journey as a novice writer in this genre creates a problem which was experienced by all of my participants. Kuntjara (2004) mentioned that most Indonesian students who study overseas and take English as their major in college in Indonesia only started to learn how to compose a paper when they studied English. She elaborated that most of us who study overseas would only learn English rhetoric in their first formal learning of writing in Indonesia 
in undergraduate program of English education with Indonesian literacy context and unfortunately this experience is not adequate to support them for their academic writing in Australia.

\section{'I have limited critical literacy practice'}

One issue of particular significance and difficulty for all my participants is the critical approach to reading and writing required in Australia compared to the one in Indonesia. My participants mentioned how important critical thinking is in the academic writing. They mentioned how they have been struggling with being critical in their academic writing in Australia. Back home in Indonesia, they were not fully aware of this thinking skill and was not demanded by their teachers and lecturers. Safnil (2000) mentioned in a broader Indonesian cultural context that reviewing previous research with a view to identifying gaps or weaknesses in the research tradition is contrary to Indonesian conceptions of politeness. Some participants stated that in Indonesia they mostly wrote descriptive and narrative essays in their education in Indonesia.

"In Indonesian, it was in narrative while descriptive is more like in academic, But I couldn't remember what about the structure or something whether they are the same or not. I haven't had like many experiences writing in Indonesia" (Sheila)

"that's probably because we have been practicing describing rather than critical thinking in Indonesian classroom." (Sheila)

The participants relate how, in contrast to Indonesian context, critical literacy is really important here in Australia. Regarding the concept of critical thinking, the participants attempted to clearly define it but it is such a complex concept and it ended up confused them. Some participants like Anir and Toni from the first focus group perceived the act of questioning things as showing off, complaining, whining, and even uncovering someone's weakness instead of being critical. They believe that this is opposed to the values in which they were raised.

Anir: "I used to see a person who very critical is kind like of very annoying person, irritating even in the conference and very criticize to what the presenter said, just shut up, I mean just accept it."

The data from the second focus group also revealed the same issues.

Maiza: "When I am here and then there are so many tasks about hmm what we call, reading critically, critical reading and give comments about certain articles so that's very useful for us in writing our own assignments or papers"

Sekar: "But then I wasn't trained that much back in bachelor studies so I really did it like instantly here.

My findings also align with Kurniati's (2008) findings in which being critical can create problems for Indonesian students. This situation can also be explained by studying the historical New Order regime where authority could not be challenged. "Incoming academics were subjected to mandatory political background checks, students were subjected to compulsory on-campus ideological indoctrination sessions, political expression and activity were outlawed on campus and students and academics who directly challenged the government were imprisoned for exercising basic rights to free expression" (Human Rights Watch, 1998). Thus, it can be concluded that socio-political and cultural values were partly the reasons why Indonesian participant felt reluctant to be more critical.

Sheila: "I felt like in the class (in Indonesia) when I was studying mostly we used mostly grammar-translation method or lecturing types so it is more like a non-critical classroom environment so we don't get to challenge ourselves like that. And then when we came (to Australia), when I came here then I start how to be critical here because we are expected to put our critical thinking in our reading especially with my assignments I have almost everything with case study so I have to critical a lot of things and then I have to support it. I can't just say it, usually in non-academic writing or just like in common conversation we just critique something without supporting (laugh) and also in writing IELTS we get used to like oh we have to do this bla bla bla but then we don't have the support. But here like, if you have something to say but you don't have supporting reference don't put it anything there." 
Anir: "I think that really affects me a lot. Even this day, I am doing thesis here where strong critical thinking is emphasized but I think if I can describe myself I tend to be descriptive person you know rather than criticizing the work of others I try to put like these he has done."

Writing in a new context forced participants to switch writing practices. it is obvious that participants are forced to be critical writer for the sake of accommodating the dominant writing practice and since they wanted to have a good grade in their study program in Australia. Thus, it can be seen that even though most of the participants studied English education, yet their experiences also varied but it is obvious that they shared limited experience in writing and explanation from their teachers and lecturers regarding argumentative texts and presenting academic criticism in writing.

\section{CONCLUSION AND RECOMMENDATION}

The data shows that the problems in the presentation of academic criticism are not solely rooted in the language barrier, in this context, English. The impact of the previous educational system in regard to the teaching of writing has not fully facilitated participants to write and articulate disagreement or criticism in the classroom. In addition, cultural values and socio-political situation in Indonesia have contributed to the participants' limited writing experience and limited critical literacy practices and the participants have struggled to present academic criticism and write according to the expected dominant discourse in Australia. Thus, Australian academics need to learn students' education background, literacy practices and embedded cultural values and socio-political practices to recognize the complexity faced by Indonesian students when they study and write in Australia. In addition, representation of the Indonesian EFL writer and learners need to be directed in more positive directions instead of continuing the persistent deficient stereotype.

\section{REFERENCES}

Alkatiri, Z. (2013). The words of magic used during the Soeharto's Indonesian New Order military regime era 1980-1997. Asian Journal of Social Sciences \& Humanities, 2 (1)

Alwasilah, A. C. (2001). Empowering college student writers through collaboration. TEFLIN journal, 12 (1)

Angelova, M., \& Riazantseva, A. (1999). "If you don't tell me, how can I know?: A case study of four international students learning to write the U.S way. Written Communication, 16 (491). doi: 10.1177/0741088399016004004

Barton, D. \& Hamilton, M. (1998). Local literacies: Reading and writing in one community. London: Routledge.

Biggs, J. (1997). Teaching across and within cultures: The issue of international students' in learning and teaching in higher education: Advancing international perspectives. HERDSA conference. Flinders Press. Adelaide.

Braun, V., \& Clarke, V. (2006). Using thematic analysis in psychology. Qualitative Research in Psychology, 3, 77-101.

Bryman, A. (2012). Social research methods: Oxford University Press.

Buchori, M. (2001). Notes on education in Indonesia. Jakarta: The Jakarta Post \& The Asia Foundation.

Cahyono, B. Y. (2001). Second language writing and rhetoric: Research studies in the Indonesian context. Malang, Indonesia: State University of Malang Press.

Canagarajah, A. S. (2002). Critical academic writing and multilingual students. Ann Arbor: University of Michigan.

Chandra, J. S. (2004). Notions of critical thinking in Javanese, Batak Toba, and Minangkabau culture. In B. N. Setiadi, A. Supratiknya, W. J. Lonner, \& Y. H. Poortinga (Eds.). Ongoing themes in psychology and culture. Retrieved from http://www.iaccp.org.

Cheng, A. (2006). Analysing and enacting academic criticism: The case of an L2 graduate learner of academic writing. Journal of Second Language Writing, 15, 279-306

Dardjowidjojo, S. (2000). English teaching in Indonesia. English Australia Journal, 18(1), 22-30. Department of Foreign Affairs and Trade of Australia. (2010). Advancing the interests of Australia and Australians internationally.

Durkin, K. (2008). The adaption of East Asian masters students to western norms of critical thinking and argumentation in the UK. Intercultural Education, 19(1), 15-27. doi: http://dx.doi.org/10.1080/14675980701852228 
Golebiowski, Zofia (1998). Rhetorical Approaches to Scientific Writing: An English-Polish Contrastive Study. Text-interdisciplinary Journal for the Study of Discourse. 18 (1)

Gunawardena, H., \& Wilson, R. (2012). International students at university: Understanding the student experience. Bern: Peter Lang.

Human Rights Watch. (1998). Academic freedom in Indonesia: Distmantling Soeharto-Era Barriers. United States of America: Human Rights Watch.

Kuntjara, E. (2004). Cultural Transfer in EFL Writing: A look at contrastive rhetoric on English and Indonesian. K@ta,6(1), 13-29.

Kurniati, A. D. (2008). Academic writing of Indonesian TESOL postgraduate students at Monash University. (Unpublished master's thesis), Monash University, Victoria, Melbourne, Australia.

Kutieleh, S., \& Egege, S. (2004). Critical thinking and International students: A marriage of necessity. Paper presented at the First year in Higher Education 2004 Conference: Dealing with diversity. Retrieved from http://hdl.handle.net/2328/12171

Leki, I. (1992). Understanding ESL Writers. USA: Boynton/Cook Publishers.

Nguyen, C. T. (2011). Challenges of learning English in Australia towards students coming from selected Southeast Asian countries: Vietnam, Thailand, and Indonesia. International Education Studies. 4 (1), 13-20.

Phan. L. H. (2011). The writing and culture nexus: Writers' comparisons of Vietnamese and English academic writing. In P. L. Ha \& B. Baurain (Eds.), Voices, identities, negotiations, and conflicts: Writing academic English across cultures (pp. 23-40). UK: Emerald Group Publishing Limited.

Safnil. (2000). Rhetorical structure analysis of the Indonesian research articles. (Unpublished Doctoral Dissertation), Australian National University, Canberra, Australia.

Salagar-Meyer, F., Alcaraz-Ariza, M. A., \& Zambrano, N. (2003). The scimitar, the dagger, and the glove: Intercultural differences in the rhetoric of criticism in Spanish, French, and English medical discourse (1930-1995). English for Specific Purpose, 22, 223-247.

Silva, T., Leki, I., \& Carson, J. (1997). Broadening the perspective of mainstream composition studies: Some thoughts from the disciplinary margins. Written Communication, 14(3), 398-428. doi: 10.1177/074108839701 4003004

Sirozi, M. (2008). Indonesian experiences in the global dynamics of international students' circulation. In H. De Wit, P. Agarwal, M. E. Said, M. T. Sehole, \& M. Sirozi (Eds.), The dynamics of international student circulation in a global context (pp. 167-198). Rotterdam: Sense Publishers. 